\title{
PENGARUH EMPLOYEE ENGAGEMENT, KOMITMEN ORGANISASI, DAN KEPEMIMPINAN \\ TRANSFORMASIONAL TERHADAP KESIAPAN UNTUK BERUBAH (READINESS FOR CHANGE) PADA KARYAWAN UNIVERSITAS AHMAD DAHLAN
}

\author{
Efi Astuti \\ efi.astuti99@gmail.com \\ Universitas Ahmad Dahlan \\ Rikha Muftia Khoirunnisa \\ move.tya@gmail.com \\ Universitas Ahmad Dahlan
}

\begin{abstract}
ABSTRAK
This study aims to determine the effect of Employee Engagement, Organizational Commitment, and Transformational Leadership on Readiness for Change in employees of Ahmad Dahlan University, Yogyakarta. The population in this study is the employees of Ahmad Dahlan University of Yogyakarta, amounting to 357 people and the sample used is 103 people, the sampling technique used is purposive sampling with sample criteria are permanent employees with a minimum working period of one year and have not moved to campus 4 UAD. The data analysis tool used is multiple linear regression test. The results of this study indicate that Employee Engagement has no effect on Readiness for Change of Ahmad Dahlan University employees. Organizational Commitment affects the Readiness for Change of Ahmad Dahlan University employees. Transformational leadership does not affect the Readiness for Change of Ahmad Dahlan University employees. And employee engagement, organizational commitment, and transformational leadership simultaneously influence the readiness for change in employees of Ahmad Dahlan University Yogyakarta
\end{abstract}

Kata kunci : Employee engagement, organizational commitment, transformational leadership, readiness for change.

\section{PENDAHULUAN}

Pesatnya perkembang bisnis saat ini menimbulkan banyak perubahan di berbagai lini, termasuk pada fungsi manajemen SDM di perusahaan/instansi mulai dibenahi dalam menghadapi setiap kemungkinan yang terjadi akibat perkembangan bisnis tersebut. Isu ekonomi, politik, sosial budaya dapat menjadi ancaman maupun peluang yang akan mempengaruhi bisnis. Hal ini akan memaksa organisasi untuk berubah.

Perubahan tren, perubahan gaya hidup masyarakat, perubahan selera konsumen, perubahan kebijakan
}

pemerintah, inovasi dan perkembangan teknologi, maupun persaingan yang semakin ketat merupakan ancaman dan peluang yang dihadapi organisasi saat ini.

Perubahan organisasi bukanlah hal yang mudah untuk dilakukan. Perubahan organisasi membutuhkan kesiapan organisasi baik dari segi operasional maupun dari segi sumber daya manusianya. Menurut Delplacess (2005) dalam Nugraheni (2012), kesiapan individu untuk berubah (readiness for organizational change) merupakan faktor pendorong yang positif. Kesiapan individu akan berdampak pula dalam fokus, perasaan, dan pola pikir yang akan terlihat 
dalam sikap dan perilakunya. Individu yang siap, akan lebih mampu menyesuaikan diri dengan perubahan dan resistensi perubahan akan berkurang. Hal ini membuat kemungkinan perubahan berhasil akan semakin besar. Holt, Armenakis, Field, dan Haris (2007) mengemukakan bahwa readiness for change adalah sebuah konstruksi multidimensional yang dipengaruhi oleh keyakinan diantara para karyawan bahwa: mereka mampu menerapkan perubahan yang diajukan (change specific efficacy), perubahan yang diajukan sesuai/tepat bagi organisasi (appropriateness), para pemimpin berkomitmen pada perubahan yang diajukan (management support), dan perubahan yang diajukan memberi keuntungan untuk organisasi (personal valence).

Guy dan Beauman (2005) dalam Zulkarnain dan Hadiyani (2014) mengemukakan bahwa kunci manajemen perubahan yang sukses adalah kompetensi organisasi, alignment dan engagement serta tekanan yang bersifatkompetitif. Konsep employee engagement masih terdapat banyak perdebatan. Engagement diartikan sebagai "keterikatan" maupun "keterlibatan" di beberapa studi dan buku. Robbins dan Judge (2017) menyatakan bahwa faktor yang membuat orang terlibat (engaged) dengan pekerjaan mereka salah satunya adalah keyakinan pekerja akan manfaat untuk terlibat dalam pekerjaan tersebut. Bukti empiris employee engagement berpengaruh terhadap kesiapan untuk berubah adalah penelitian yang dilakukan oleh Zulkarnain dan Hadiyani (2014) yang membuktikan bahwa employee engagement merupakan prediktor positif kesiapan untuk berubah (readiness for change). Menurut Kahn (1990) dalam Saks (2006) employee engagement merupakan bentuk multidimensional dari aspek emosi, kognitif, dan fisik karyawan yang saling terikat.

Hal penting dalam sebuah perubahan, tentu karyawan dituntut untuk keluar dari zona nyaman, dan tidak semua karyawan siap dengan hal ini. Banyak karyawan yang pesimis dan berakhir dengan pengunduran diri. Sehingga komitmen organisasi memainkan peran penting terkait dengan kesiapan karyawan untuk berubah. Hal ini dibuktikan dalam penelitian yang dilakukan oleh Periantalo dan Mansoer (2008) yang membuktikan bahwa affective commitment dan continuance commitment berpengaruh terhadap kesiapan untuk berubah (readiness for change).

Dalam Luthans (2006), komitmen organisasi didefinisikan sebagai keinginan kuat untuk tetap menjadi anggota suatu organisasi, keinginan untuk bekerja keras sesuai harapan organisasi, keyakinan tertentu serta penerimaan nilai dan tujuan organsasi. Komitmen organisasi merefleksikan loyalitas karyawan pada organisasi dan proses berkelanjutan dimana anggota organisasi mengekspresikan perhatiannya terhadap organisasi dan keberhasilan serta kemajuan yang berkelanjutan. Menurut model Mayer dan Allen (1991) dalam Luthans (2006), komitmen organisasi memiliki 3 dimensi yaitu komitmen afektif, komitmen berkelanjutan, dan komitmen normatif. Komitmen afektif yaitu keterikatan emosional karyawan, identifikasi, dan partisipasi dalam organisasi. Sedangkan komitmen berkelanjutan adalah komitmen berdasarkan kerugian yang berhubungan dengan keluarnya karyawan dari organisasi. Selanjutnya, komitmen normatif adalah perasaan wajib untuk tetap berada dalam organisasi karena memang harus begitu (perasaan atau sugesti bahwa tindakan tersebut merupakan hal benar yang harus dilakukan).

Disamping employee engagement dan komitmen organisasi, peran seorang pemimpin juga sangat penting untuk mengarahkan, membimbing, dan memotivasi bawahan dalam usaha untuk berubah. Peran seorang pemimpin sangat penting dalam membangun kepercayaan 
diri karyawan dalam menghadapi perubahan4 organisasi. Walumbwa, Avolio, dan Zhu (2008) dalam Robbins dan Judge (2017) menerangkan bahwa kepemimpinan transformasional merupakan salah satu gaya kepemimpinan yang mendukung kesiapan untuk berubah karena para pemimpin yang transformasional dapat meningkatkan efektifitas para pengikut dan memberi semangat "pasti dapat melakukan." Robbins dan Judge (2017) juga menyatakan kepemimpinan transformasional adalah gaya kepemimpinan yang dapat menginspirasi dan memotivasi bawahan untuk melaksanakan tugas diatas ekspektasi dan melampaui kepentingan diri mereka sendiri demi kepentingan organisasi. Bukti empirisnya ditemukan pada penelitian yang dilakukan oleh Kartika (2016) yang membuktikan bahwa kepemimpinan transformasional (transformational leadership) berpengaruh terhadap kesiapan untuk berubah (readiness for change). Lebih lanjut Robbins dan Judge (2017) juga menjelaskan bahwa kepemimpinan transformasional adalah gaya kepemimpinan yang perhatian pada kekhawatiran dan kebutuhan dari para pengikut, mengubah kesadaran atas permasalahan mereka dangan membantu mereka melihat permasalahan lama melalui cara yang baru, membangkitkan semangat mereka dan menginspirasi untuk menempatkan upaya tambahan dan seterusnya demi mencapai tujuan - tujuan kelompok.

\section{Rumusan Masalah}

1. Apakah employee engagement berpengaruh terhadap kesiapan untuk berubah (readiness for change) pada karyawan Universitas Ahmad Dahlan Yogyakarta?

2. Apakah komitmen organisasi berpengaruh terhadap kesiapan untuk berubah (readiness for change) pada karyawan Universitas Ahmad Dahlan Yogyakarta?
3. Apakah transformasional kepemimpinan terhadap kesiapan untuk berubah (readiness for change) pada karyawan Universitas Ahmad Dahlan Yogyakarta?

4. Apakah employee engagement, komitmen organisasi, dan kepemimpinan transformasional berpengaruh secara simultan terhadap kesiapan untuk berubah (readiness for change) pada karyawan Universitas Ahmad Dahlan Yogyakarta?

\section{REVIEW LITERATUR DAN HIPOTESIS}

\section{Landasan Teori}

\section{Kesiapan untuk Berubah (Readiness for Change)}

\section{a. Perubahan Organisasi}

Semua organisasi menghadapi lingkungan yang dinamis sehingga selalu ada perubahan. Konsep tentang perubahan diartikan sebagai beralihnya keadaan sebelumnya (the before) menjadi keadaan setelahnya (the after). Cook et.al. (1997) dalam Nawawi (2014) mendefinisikan perubahan sebagai proses dimana terdapat perpindahan dari kondisi yang berlaku menuju kondisi yang diinginkan yang dilakukan oleh individu, kelompok, maupun organisasi sebagai bentuk reaksi terhadap dorongan internal maupun eksternal. Sedangkan Robbins dan Coulter (2008) mengartikan perubahan dengan membuat sesuatu menjadi lain. Alasan pentingnya perubahan adalah manajer maupun organisasi menginginkan agar bisnisnya dapat bertahan dan memiliki daya saing yang kompetitif.

\section{b. Kesiapan untuk Berubah (Readiness for Change)}

Kesiapan untuk berubah (readiness for change) dikemukakan oleh Hanpachern (1997) dalam Nugraheni (2012) sebagai sejauhmana individu individu secara mental, psikologis atau 
fisik siap, atau bersemangat untuk berpartisipasi dalam kegiatan pengembangan organisasi.

\section{c. Pentingnya Kesiapan untuk Berubah}

Dunia bisnis semakin dinamis, banyak dorongan-dorongan perubahan baik dari internal maupun dari eksternal perusahaan serta adanya kekuatankekuatan yang mendasari terjadinya perubahan membuat perusahaan harus siap dan mampu melakukan perubahan. Konsumen menuntut lebih dari yang dilakukannya dimasa lalu, karena itu Hussey (2000) dalam Wibowo (2012) menyebutkan salah satu faktor pendorong perubahan adalah kebutuhan untuk berubah. Lingkungan selalu berubah, dan perusahaan memiliki kebutuhan untuk berubah demi mempertahankan eksistensi dan mampu bersaing. Banyak perusahaan merencanakan perubahan untuk membenahi sistem, mengatasi permasalahpermasalahan dan membentuk suatu keunggulan bersaing, namun perubahan yang direncanakan terkadang tidak berjalan sesuai harapan. Banyak keraguan dan ketakutan akan kegagalan karena kurangnya kesiapan untuk berubah dari para karyawan. Eby et.al. (2000) dalam Zulkarnain dan Hadiyani (2014) menjelaskan bahwa organisasi yang hendak melakukan perubahan sangat membutuhkan dukungan terbuka karyawan yang mampu mempersiapkan diri dengan baik dan siap untuk berubah. Bernerth (2004) dalam Zulkarnain dan Hadiyani (2014) menemukan bahwa faktor keberhasilan perubahan organisasi adalah kesiapan karyawan dalam berubah. Hal tersebut membuktikan bahwa kesiapan untuk mberubah karyawan merupakan faktor penting demi tercapainya hasil perubahan yang diharapkan.

\section{Employee Engagement}

\section{a. Definisi Employee Engagement}

Konsep employee engagement masih terdapat banyak perdebatan. Engagement diartikan sebagai "keterikatan" maupun "keterlibatan" di beberapa studi dan buku. Robinson et.al., (2004) dan Rafferty et.al., (2005) dalam Rachmawati (2010) mengemukakan bahwa employee engagement merupakan pengembangan dari dua konsep terdahulu, yaitu komitmen dan Organizational Citizenship Behavior. Konsep employee engagement memiliki kemiripan dengan kedua konsep terdahulunya dan kadang definisinya sering tumpang18 tindih. Robinson et.al., (2004) dalam Rachmawati (2010) menyebutkan bahwa kedua konsep terdahulu yaitu komitmen dan OCB dirasa kurang lengkap, dan didalam konsep employee engagement, dimasukkan unsur kesadaran bisnis (business awareness). Namun employee engagement berbeda dengan kedua konsep terdahulu yaitu komitmen dan OCB. Rafferty et.al. (2005) dalam Rachmawati (2010) juga membedakan antara konsep employee engagement dengan komitmen dan OCB, dimana employee engagement lebih menunjukkan proses saling memberi dan menerima yang menguntungkan antara karyawan dan organisasi/perusahaan.

\section{b. Dimensi Employee Engagement}

Menurut Schaufeli dan Bakker (2004) dalam Akbar (2013) disebutkan bahwa ada tiga karakteristik dalam employee engagement, yaitu:

1) Vigor dikarakteristikan dengan level energi yang tinggi dan ketangguhan mental saat bekerja, serta keinginan untuk mencurahkan segenap usaha dalam pekerjaan, dan juga ketahanan dalam menghadapi kesulitan.

2) Dedication dikarakteristikan dengan rasa antusias, inspirasi, kebanggaan dan tantangan.

3) Absorption dikarakteristikan dengan berkonsentrasi penuh dan senang ketika terlibat dalam pekerjaan, sehingga waktu akan terasa berjalan dengan cepat sekalipun seorang karyawan sedang menghadapi masalah 


\section{c. Pentingnya Employee Engagement}

Finney (2011) menyatakan bahwa karyawan yang engaged pada pekerjaannya adalah impian para manajer karena karyawan yang memiliki ikatan dengan pekerjaan, mereka mempercayai misi organisasi mereka. Memiliki karyawan yang engaged akan mendatangkan banyak manfaat.

\section{Komitmen Organisasi}

\section{a. Pengertian Komitmen Organisasi}

Luthans (2006) mendefinisikan komitmen organisasi sebagai keinginan kuat untuk tetap menjadi anggota suatu organisasi, keinginan untuk bekerja keras sesuai harapan organisasi, keyakinan tertentu serta penerimaan nilai dan tujuan organsasi. Komitmen organisasi merefleksikan loyalitas karyawan pada organisasi dan proses berkelanjutan dimana anggota organisasi mengekspresikan perhatiannya terhadap organisasi dan keberhasilan serta kemajuan yang berkelanjutan. Sedangkan menurut Robbins dan Coulter (2008) menyebutkan bahwa komitmen organisasi merupakan derajat dimana seorang karyawan mengidentifikasikan dirinya dengan organisasi beserta tujuannya dan berkeinginan untuk mempertahankan keanggotaannya dalam organisasi tersebut. Yousef (2000) dalam Zulkarnain dan Hadiyani (2014) menjelaskan bahwa terdapat beberapa peneliti menyebutkan bahwa komitmen organisasi memainkan peranan penting dalam penerimaan karyawan terhadap perubahan dan komitmen organisasi juga secara langsung mempengaruhi sikap terhadap perubahan organisasi dan kepuasan kerja.

\section{b. Dimensi Komitmen Organisasi}

Menurut model Mayer dan Allen (1991) dalam Luthans (2006), komitmen organisasi memiliki 3 dimensi yaitu:

1) Komitmen afektif yaitu keterikatan emosional karyawan, identifikasi, dan partisipasi dalam organisasi.
2) Komitmen berkelanjutan adalah komitmen berdasarkan kerugian yang berhubungan dengan keluarnya karyawan dari organisasi.

3) Komitmen normatif adalah perasaan wajib untuk tetap berada dalam organisasi karena memang harus begitu (perasaan atau sugesti bahwa tindakan tersebut merupakan hal benar yang harus dilakukan).

\section{c. Anteseden Komitmen Organisasi}

Kreitner dan Kinicki (2014) menjabarkan anteseden (penyebab munculnya komponen komitmen) dari ketiga jenis komitmen diatas (komitmen afektif, komitmen berkelanjutan, dan komitmen normatif) yaitu:

1) Anteseden komitmen afektif berhubungan dengan berbagai karakteristik pribadi, seperti kepribadian (kombinasi karakteristik fisik dan mental yang stabil yang memberikan identitas kepada individu) dan lokus kendali internal (menghubungkan hasil dengan tindakan sendiri) maupun eksternal (menghubungkan hasil keadaan pada sebab-sebab di luar kendali seseorang seperti dari lingkungan), pengalaman kerja pada masa lalu, kongruen nilai (mencerminkan kesamaan nilai individu dengan sistem nilai budaya suatu perusahaan).

2) Anteseden komitmen berkelanjutan yaitu segala sesuatu yang mempengaruhi jumlah investasi nyata dan psikologi yang dimiliki seseorang dalam organisasi atau masyarakat. Komitmen berkelanjutan akan semakin tinggi jika seseorang tidak memiliki pekerjaan lain, terlibat secara aktif dalam kegiatan keagamaannya, dan memiliki banyak teman di masyarakat.

3) Anteseden komitmen normatif dipengaruhi oleh proses sosialisasi dan kontrak psikologis. Kontrak 
psikologis yaitu keyakinan akan apa yang dia terima atas apa yang dia berikan.

\section{d. Pentingnya Komitmen Organisasi}

Seperti yang dijelaskan oleh Luthans (2006), komitmen organisasi merupakan keinginan kuat untuk tetap menjadi anggota suatu organisasi, keinginan untuk bekerja keras sesuai harapan organisasi, keyakinan tertentu serta penerimaan nilai dan tujuan organsasi serta refleksi dari loyalitas karyawan pada organisasi dan proses berkelanjutan dimana anggota organisasi mengekspresikan perhatiannya terhadap organisasi dan keberhasilan serta kemajuan yang berkelanjutan. Dari definisi tersebut tentu komitmen merupakan hal yang penting karena karyawan yang berkomitmen akan menerima nilai-nilai organisasi serta perhatiannya keberhasilan dan kemajuan organisasinya dan siap bekerja keras demi organisasi. Karyawan yang berkomitmen memiliki keinginan untuk tetap tinggal dalam organisasi sehingga tidak mudah berpindah dan hal ini merupakan keuntungan bagi perusahaan.

\section{Kepemimpinan Transformasional \\ a. Definisi Kepemimpinan}

Kepemimpinan menurut Kreitner dan Kinicki (2015) adalah sebuah proses dimana seorang individu mempengaruhi yang lain untk mencapai sasaran yang sama. Kepemimpinan (leadership) didefinisikan sebagai kemampuan untuk mengarahkan orang lain guna mencapai tujuan organisasi (Daft, 2012). Sedangkan Soetopo (2010) dalam Setiawan dan Muhith (2013) menyebut kepemimpinan sebagai proses mempengaruhi, mengarahkan, dan mengoordinasi segala kegiatan organisasi atau kelompok untuk mencapai tujuan oganisasi atau kelmpok. Menurut Lensufiie (2010) kepemimpinan memilki arti lebih dari sekedar label atau jabatan yang diberikan kepada seseorang, melainkan ada unsur visi jangka panjang serta karakter dalam sebuah kepemimpinan. Lensufiie (2010) menerangkan beberapa komponen komponen didalam kepemimpinan, yaitu:

\section{b. Kepemimpinan Transformational (Transformational Leadership)}

Istilah Kepemimpinan transfrmasional (Transformational Leadership) dimunculkan dimunculkan pertama kali pada tahun 1973 oleh Downton. Kemudian James McGregor Burns, seorang sosiolog politik, menulis buku leadership pada tahun 1978 yang mengungkapkan bahwa seorang pemimpin menangkap motivasi para pengikutnya dengan tujuan untuk mencapai tujuan bersama (Lensufiie, 2010). Kepemimpinan transformasional merupakan gabungan dua kata yaitu kepemimpinan dan transformasional. Transformasional atau transformasi berarti perubahan rupa (bentuk sifat, fungsi). Ada juga yang mengartikan transformasional dari induk kata "to transform" yaitu mentransformasikan atau mengubah sesuatu menjadi bentuk lain yang berbeda.

\section{c. Dimensi Kepemimpinan Transformasional \\ Dalam Setiawan dan Muhith (2013),} dijabarkan empat dimensi/komponen kepemimpinan transformasional sebagai berikut:

1) Idealized influences-charisma. Merupakan perilaku pemimpin yang yang memiliki keyakinan kuat, komitmen tinggi, visi yang jelas, tekun, pekerja keras dan militan, konsisten, mampu menunjukkan ideide penting, memberikan wawasan serta kesadaran akan visi dan misi organisasi serta membangun dan membangkitkan kebanggaan akan eksistensi organisasi tersebut. Kepemimpinan ini menumbuhkan sikap hormat dan kepercayaan bawahan terhadap organisasinya. Artinya didalam kepemimpinannya, 
pola perilaku pemimpin yang menjadi suri tauladan para pengikut.

2) Inspirational motivation. Merupakan pola perilaku pemimpin yang menginspirasi dan memotivasi para pengikut untuk mengejar kemungkinan yang lebih tinggi dan mengajak pengikut untuk memandang permasalahan sebagai kesempatan untuk belajar dan berprestasi.

3) Intellectual stimulation. Kepemimpinann yang berupaya meningkatkan kesadaran terhadap masalah diri dan organisasi, memandang masalah tersebut dengan perspektif yang baru dan memfasilitasi untuk berusaha bersama meningkatkan intelegensi, rasionalitas, dan pemecahan masalah secara seksama.

4) Individualized considerations. Perilaku pemimpin yang memberi perhatian, bimbingan, menciptakan ruang gerak dan melatih para pengikut.

\section{d. Pentingnya Transformasional}

Kepemimpinan

Karakter dari kepemimpinan transformasional diperlukan oleh perusahaan karena kepemimpinan ini menumbuhkan sikap hormat dan kepercayaan bawahan terhadap organisasinya, memotivasi dan menginspirasi, perhatian dan membimbing serta menciptakan ruang gerak dan melatih para pengikut. Kepemimpinan transformasional penting bagi perusahaan, terutama disaat menghadapi perubahan. Bass (1985) dalam Nugraheni (2012) menyatakan bahwa selama proses perubahan yang terjadi dalam organisasi, kepemimpinan transformasional memiliki peran yang lebih efektif. Setiawan dan Muhith (2013) juga mengemukakan bahwa kepemimpinan transformasional mendapat banyak perhatian karena kepemimpinan transformasional membawa perubahan adaptif dalam organisasi sehingga lebih kental nuansa "kebersamaan berdasarkan solidaritas" dibanding kepemimpinan yang cenderung memelihara status quo dengan tingkat komponen organisasi pembelajar sangat rendah. Selain itu beberapa peneliti seperti Kartika (2016) membuktikan bahwa terdapat pengaruh antara kepemimpinan transformasional dengan kesiapan untuk berubah.

\section{Penelitian Terdahulu}

\begin{tabular}{|c|c|c|c|}
\hline \multicolumn{4}{|c|}{ Penelitian Terdahulu } \\
\hline $\begin{array}{l}\text { Peneliti } \\
\text { (tahun) }\end{array}$ & Variabel & Responden & Hasil \\
\hline $\begin{array}{l}\text { Zulkarnain } \\
\text { dan } \\
\text { Hadiyani } \\
(2014)\end{array}$ & $\begin{array}{l}\text { a. Employee engagement } \\
\text { b.Komitmen organisasi } \\
\text { c. Kesiapan untuk berubah }\end{array}$ & $\begin{array}{l}\text { Karyawan PT. } \\
\text { Perkebunan } \\
\text { Nusantara III } \\
\text { Medan }\end{array}$ & $\begin{array}{l}\text { Employee engagement } \\
\text { dan komitmen } \\
\text { organisasi } \\
\text { berpengaruh terhadap } \\
\text { kesiapan karyawan } \\
\text { untuk berubah } \\
\end{array}$ \\
\hline $\begin{array}{l}\text { Megani } \\
\text { (2012) }\end{array}$ & $\begin{array}{l}\text { a. Employee engagement } \\
\text { b. Kesiapan untuk berubah }\end{array}$ & $\begin{array}{l}\text { Karyawan PT. } \\
\text { X }\end{array}$ & \begin{tabular}{|l|} 
Employee engagement \\
berpengaruh dan \\
memberikan \\
sumbangan terbesar \\
yaitu $26.2 \%$ terhadap \\
kesiapan untuk \\
berubah r \\
\end{tabular} \\
\hline $\begin{array}{l}\text { Periantalo } \\
\text { dan } \\
\text { Mansoer } \\
\text { (2008). }\end{array}$ & $\begin{array}{l}\text { a. Keadilan organisasi } \\
\text { b. komitmen organisasi } \\
\text { c. Dukungan organisasi } \\
\text { d. Iklim psikologis. } \\
\text { e. Kesiapan untuk berubah }\end{array}$ & $\begin{array}{l}\text { Karyawan dari } \\
10 \text { kantor } \\
\text { cabang Dirjen } \\
\text { PQR di } \\
\text { wilayah DKI } \\
\text { Jakarta }\end{array}$ & $\begin{array}{l}\text { Affective commitment } \\
\text { dan continuance } \\
\text { commitment } \\
\text { berpengaruh terhadap } \\
\text { kesiapan untuk } \\
\text { berubah (readiness for } \\
\text { change). } \\
\end{array}$ \\
\hline $\begin{array}{l}\text { Fitrianna } \\
\text { dan } \\
\text { Agustina } \\
(2015)\end{array}$ & $\begin{array}{l}\text { a. Transformational } \\
\text { leadership } \\
\text { b. Commitmen to change } \\
\text { c. Readiness for change }\end{array}$ & $\begin{array}{l}\text { Karyawan } \\
\text { tetap dan } \\
\text { karyawan yang } \\
\text { berada pada } \\
\text { level jabatan } \\
\text { staff. }\end{array}$ & \begin{tabular}{|l|} 
Terdapat pengaruh \\
variabel \\
transformational \\
leadership terhadap \\
readiness for change
\end{tabular} \\
\hline $\begin{array}{l}\text { Laensadi } \\
\text { (2015) }\end{array}$ & $\begin{array}{l}\text { a. Kepemimpinan } \\
\text { transformasional } \\
\text { b. Faktor demografik } \\
\text { c. Kesiapan untuk berubah }\end{array}$ & $\begin{array}{l}\text { Dosen dan } \\
\text { karyawan } \\
\text { IAIN Sultan } \\
\text { Thaha } \\
\text { Saifuddin } \\
\text { Jambi }\end{array}$ & $\begin{array}{l}\text { Terdapat pengaruh } \\
\text { variabel } \\
\text { kepemimpinan } \\
\text { transformasional } \\
\text { terhadap readiness for } \\
\text { change. }\end{array}$ \\
\hline $\begin{array}{l}\text { Kartika } \\
\text { (2016) }\end{array}$ & $\begin{array}{l}\text { a. Transformational } \\
\text { leadership } \\
\text { b. Employee engagement } \\
\text { c. readiness for change }\end{array}$ & $\begin{array}{l}\text { Karyawan } \\
\text { devisi Factory } \\
\text { PT. Suparma, } \\
\text { Tbk. }\end{array}$ & $\begin{array}{l}\text { Transformational } \\
\text { leadership } \\
\text { berpengaruh terhadap } \\
\text { readiness for change. }\end{array}$ \\
\hline
\end{tabular}

\section{Hipotesis}

$\mathrm{H1}$ : Employee engagement berpengaruh terhadap kesiapan untuk berubah (readiness for change) pada karyawan Universitas Ahmad Dahlan Yogyakarta.

$\mathrm{H} 2$ : Komitmen organisasi berpengaruh terhadap kesiapan untuk berubah (readiness for change) pada karyawan Universitas Ahmad Dahlan Yogyakarta

H3: Kepemimpinan transformasional berpengaruh terhadap kesiapan untuk berubah (readiness for change) pada karyawan Universitas Ahmad Dahlan Yogyakarta.

$\mathrm{H} 4$ : Employee engagement, komitmen organisasi, dan kepemimpinan transformasional secara simultan 
berpengaruh terhadap kesiapan untuk berubah (readiness for change) pada karyawan Universitas Ahmad Dahlan Yogyakarta.

\section{METODE PENELITIAN}

\section{Populasi dan Sampel}

Sekaran (2003) dalam Zulganef (2008) mendefinisikan populasi sebagai keseluruhan kelompok orang, kejadian, atau hal-hal yang bagipeneliti menarik untuk diteliti. Populasi adalah wilayah generalisasi yang terdiri dari obyek/subyek yang mempunyai kualitas dan karakteristik tertentu yang ditetapkan oleh peneliti untuk dipelajari dan kemudian ditarik kesimpulannya (Sugiyono, 2015). Populasi dalam penelitian ini adalah seluruh karyawan Universitas Ahmad Dahlan Yogyakarta.

Menurut Sugiyono (2015) sampel adalah bagian dari jumlah dan karakteristik yang dimiliki oleh populasi tersebut. Sampel didefinisikan sebagai bagian atau subset dari populasi yang terdiri dari anggota-anggota populasi yang terpilih (Zulganef, 2008). Sample dalam penelitian ini adalah sebagian karyawan Universitas Ahmad Dahlan Yogyakarta. Penentuan ukuran sampel dalam penelitian ini mengacu pada pendapat Roscoe (1982) dalam Sugiyono (2015) yaitu bila dalam penelitian akan melakukan analisis dengan multivariate (korelasi atau regresi ganda misalnya), maka jumlah anggota sampel minimal 10 kali dari jumlah variabel yang diteliti. Misal variabel yang diteliti ada 5 (independen +38 dependen), maka jumlah anggota sampel $=10 \times 5=50$. Berdasarkan acuan tersebut, maka ukuran sampel dalam penelitian ini minimal 40 orang (4 x 10).

\section{Definisi Operasional}

1. Variabel Independen

Variabel independen dalam bahasa Indonesia sering disebut variabel bebas. Variabel bebas adalah variabel yang mempengaruhi atau menjadi sebab perubahannya atau timbulnya variabel dependen (Sugiyono, 2015). Dalam penelitian ini yang menjadi variabel independen adalah employee engagement, komitmen organisasi, dan kepemimpinan transformasional.

\section{a. Employee Engagement}

Kreitner dan Kinicki

(2014) menyatakan bahwa keterikatan pegawai (employee engagement) merupakan keterlibatan, kepuasan, dan antusiasme karyawan untuk bekerja. Menurut Schaufeli dan Bakker (2004) dalam Akbar (2013), ada tiga karakteristik dalam employee engagement, yaitu:

Indikator Employee Engagement

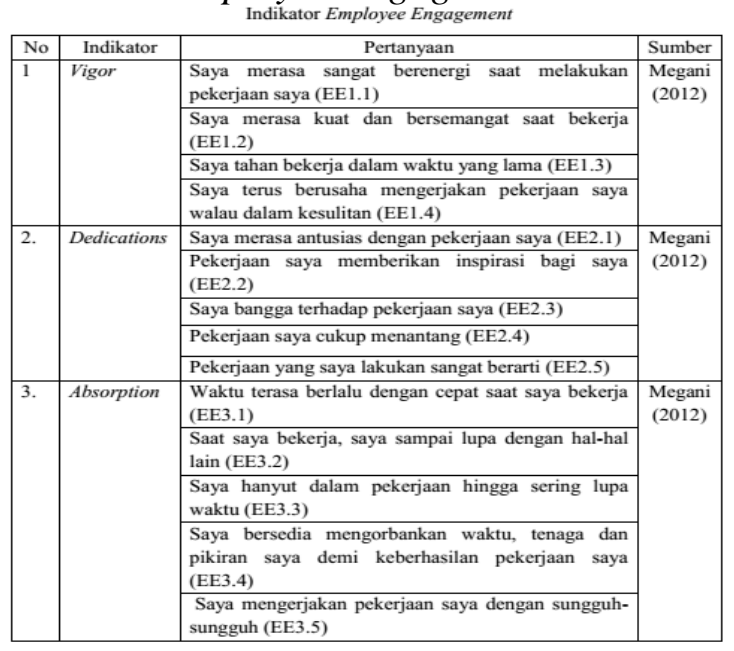

b. Komitmen Organisasi

Komitmen organisasi disini adalah keinginan kuat karyawan untuk tetap menjadi anggota organisasi. Menurut model Mayer dan Allen (1991) dalam Luthans (2006), komitmen organisasi memiliki 3 dimensi yaitu:

1) Komitmen afektif yaitu keterikatan emosional karyawan, identifikasi, dan partisipasi dalam organisasi.

2) Komitmen berkelanjutan adalah komitmen berdasarkan kerugian yang berhubungan dengan keluarnya karyawan dari organisasi.

3) Komitmen normatif adalah perasaan wajib untuk tetap berada dalam organisasi karena memang harus begitu (perasaan atau sugesti bahwa tindakan tersebut merupakan hal benar yang harus dilakukan). 
Indikator Komitmen Oraganisasi

\begin{tabular}{|c|c|c|c|}
\hline No & Indikator & Pertanyaan & Sumber \\
\hline \multirow[t]{5}{*}{1} & \multirow[t]{5}{*}{$\begin{array}{l}\text { Komitmen } \\
\text { afektif }\end{array}$} & $\begin{array}{l}\text { Saya merasa memiliki keterikatan emosional } \\
\text { dengan UAD sehingga saya merasa sulit untuk } \\
\text { berpindah kerja (KO1.1) }\end{array}$ & \multirow[t]{5}{*}{$\begin{array}{c}\text { Nurafiah } \\
(2012)\end{array}$} \\
\hline & & $\begin{array}{l}\text { Saya merasa seperti bagian keluarga di UAD } \\
\text { (KO1.2) }\end{array}$ & \\
\hline & & $\begin{array}{l}\text { Saya merasa bangga menjadi bagian dari UAD } \\
\text { (KO1.3) }\end{array}$ & \\
\hline & & $\begin{array}{l}\text { Saya bersedia bekerja lembur demi mencapai } \\
\text { target UAD (KO1.4) }\end{array}$ & \\
\hline & & $\begin{array}{l}\text { Saya merasa masalah UAD merupakan masalah } \\
\text { saya juga (KO1.5) }\end{array}$ & \\
\hline \multirow[t]{5}{*}{2.} & \multirow[t]{2}{*}{$\begin{array}{l}\text { Komitmen } \\
\text { berkelanjut } \\
\text { an }\end{array}$} & $\begin{array}{l}\text { Akan sangat berat bagi saya untuk meninggalkan } \\
\text { UAD sekarang sekalipun saya menginginkannya } \\
\text { (KO2.1) }\end{array}$ & \multirow[t]{2}{*}{$\begin{array}{l}\text { Rimata } \\
(2014)\end{array}$} \\
\hline & & Bagi saya bekerja di UAD merupakan kebutuhan & \\
\hline & & sekaligus juga keinginan saya $(\mathrm{KO} 2.2)$ & \\
\hline & & $\begin{array}{l}\text { Saya berfikir jika meninggalkan UAD akan } \\
\text { membutuhkan pengorbanan pribadi yang besar } \\
\text { (KO2.3) }\end{array}$ & \\
\hline & & $\begin{array}{l}\text { Jika saya pindah kerja, saya tidak akan } \\
\text { mendapatkan manfaat seperti yang saya dapat } \\
\text { UAD (KO2.4) }\end{array}$ & \\
\hline \multirow[t]{5}{*}{3.} & \multirow[t]{5}{*}{$\begin{array}{l}\text { Komitmen } \\
\text { normatif }\end{array}$} & $\begin{array}{l}\text { Menurut saya, menunjukkan loyalitas kepada } \\
\text { UAD merupakan hal yang penting ( } \mathrm{KO} 3.1)\end{array}$ & \multirow[t]{4}{*}{$\begin{array}{c}\text { Nurafiah } \\
(2012)\end{array}$} \\
\hline & & $\begin{array}{l}\text { UAD telah memberi banyak bantuan kepada } \\
\text { saya (KO3.2) }\end{array}$ & \\
\hline & & $\begin{array}{l}\text { Saya akan merasa bersalah jika meninggalkan } \\
\text { UAD (KO3.3) }\end{array}$ & \\
\hline & & $\begin{array}{l}\text { UAD pantas mendapatkan loyalitas saya } \\
\text { (KO3.4) }\end{array}$ & \\
\hline & & $\begin{array}{l}\text { Berpindah dari satu tempat kerja ke tempat kerja } \\
\text { lain tampaknya tidak etis bagi saya (KO3.5) }\end{array}$ & $\begin{array}{l}\text { Rimata } \\
(2014)\end{array}$ \\
\hline
\end{tabular}

c. Kepemimpinan Transformasional

Robbins dan Judge (2017) juga menjelaskan bahwa kepemimpinan transformasional adalah gaya kepemimpinan yang perhatian pada kekhawatiran dan kebutuhan dari para pengikut, mengubah kesadaran atas permasalahan mereka dangan membantu mereka melihat permasalahan lama melalui cara yang baru, membangkitkan semangat mereka, dan menginspirasi untuk menempatkan upaya tambahan dan seterusnya demi mencapai tujuan - tujuan kelompok.

Dalam Setiawan dan Muhith (2013) dijabarkan empat komponen kepemimpinan transformasional sebagai berikut:

1) Idealized influences-charisma merupakan perilaku pemimpin yang yang memiliki keyakinan kuat, komitmen tinggi, visi yang jelas, tekun, pekerja keras dan militan, konsisten, mampu menunjukkan ideide penting, memberikan wawasan serta kesadaran akan visi dan misi organisasi serta membangun dan membangkitkan kebanggaan akan eksistensi organisasi tersebut. Kepemimpinan ini menumbuhkan sikap hormat dan kepercayaan anggotanya terhadap organisasinya. Artinya didalam kepemimpinannya, pola perilaku pemimpin yang menjadi suritauladan para pengikut.

2) Inspirational motivation merupakan pola perilaku pemimpin yang menginspirasi dan memotivasi para pengikut untuk mengejar kemungkinan yang lebih tinggi dan mengajak pengikut untuk memandang permasalahan sebagai kesempatan untuk belajar dan berprestasi.

3) Intellectual stimulation merupakan perilaku dari pemimpin yang berupaya meningkatkan kesadaran terhadap masalah diri dan organisasi dan memandang masalah tersebut dengan perspektif yang baru dan memfasilitasi untuk berusaha bersama meningkatkan intelegensi, rasionalitas, dan pemecahan masalah secara seksama.

4) Individualized considerations yaitu perilaku pemimpin yang memberi perhatian, bimbingan, menciptakan ruang gerak dan melatih para pengikut. 
Indikator Kepemimpinan Transformasional

\begin{tabular}{|c|c|c|c|}
\hline No & Apek & Pertanyaan & Sumber \\
\hline \multirow[t]{4}{*}{1} & \multirow[t]{4}{*}{$\begin{array}{l}\text { Idealized } \\
\text { influences }\end{array}$} & $\begin{array}{l}\text { Pimpinan saya merupakan panutan bagi para } \\
\text { bahawannya (KT1.1) }\end{array}$ & \multirow[t]{4}{*}{$\begin{array}{c}\text { Nurafiah } \\
(2012)\end{array}$} \\
\hline & & $\begin{array}{l}\text { Pimpinan saya memberikan petunjuk kepada } \\
\text { bawahannya bagaimana menyelesaikan suatu } \\
\text { pekerjaan (KT1.2) }\end{array}$ & \\
\hline & & $\begin{array}{l}\text { Pimpinan saya menanamkan rasa } \\
\text { bergabung bersamanya (KT1.3) }\end{array}$ & \\
\hline & & $\begin{array}{l}\text { Pimpinan saya mendapatkan rasa hormat dari para } \\
\text { pegawai }(\mathrm{KT} 1.4)\end{array}$ & \\
\hline \multirow[t]{5}{*}{2.} & \multirow[t]{5}{*}{$\begin{array}{l}\text { Inspirational } \\
\text { motivation }\end{array}$} & $\begin{array}{l}\text { Pimpinan saya memberi motivasi kepada bawahan } \\
\text { untuk bekerja lebih baik (KT2.1) }\end{array}$ & \multirow[t]{5}{*}{$\begin{array}{c}\text { Nurafiah } \\
(2012)\end{array}$} \\
\hline & & $\begin{array}{l}\text { Pimpinan saya menumbuhkan rasa percaya diri } \\
\text { bawahannya dalam melakukan pekerjaan (KT2.2) }\end{array}$ & \\
\hline & & $\begin{array}{l}\text { Pimpinan saya memberi keyakinan kepada } \\
\text { bawahan bahwa tujuan organisasi akan tercapai } \\
\text { (KT2.3) }\end{array}$ & \\
\hline & & $\begin{array}{l}\text { Pimpinan saya membangkitkan rasa antusiasme } \\
\text { bawahan untuk melakukan pekerjaan (KT2.4) }\end{array}$ & \\
\hline & & $\begin{array}{l}\text { Pimpinan saya melakukan komunikasi tentang } \\
\text { pekerjaan dengan jelas (KT2.5) }\end{array}$ & \\
\hline \multirow[t]{4}{*}{3.} & \multirow[t]{4}{*}{$\begin{array}{l}\text { Intellectual } \\
\text { stimulation }\end{array}$} & $\begin{array}{l}\text { Pimpinan saya mendorong bawahannya untuk } \\
\text { menggunakan kreativitas dalam menyelesaikan } \\
\text { pekerjaan (KT3.1) }\end{array}$ & \multirow[t]{4}{*}{$\begin{array}{l}\text { Nurafiah } \\
(2012)\end{array}$} \\
\hline & & $\begin{array}{l}\text { Pimpinan saya mendorong bawahannya untuk } \\
\text { selalu inovatif dalam menyelesaikan pekerjaan } \\
\text { (KT3.2) }\end{array}$ & \\
\hline & & $\begin{array}{l}\text { Pimpinan saya bersemangat untuk mendengarkan } \\
\text { ide/gagasan baru dari bawahan (KT3.3) }\end{array}$ & \\
\hline & & 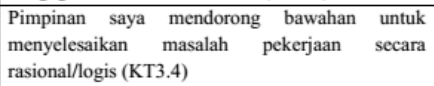 & \\
\hline \multirow[t]{4}{*}{4.} & \multirow[t]{3}{*}{$\begin{array}{l}\text { Individualized } \\
\text { considerations }\end{array}$} & $\begin{array}{l}\text { Pimpinan saya berupaya meningkatkan } \\
\text { pengembangan diri bawahan (KT4.1) }\end{array}$ & \multirow[t]{3}{*}{$\begin{array}{c}\text { Nurafiah } \\
(2012)\end{array}$} \\
\hline & & $\begin{array}{l}\text { Pimpinan saya bersedia mendengarkan keluhan } \\
\text { bawahan (KT4.2) }\end{array}$ & \\
\hline & & $\begin{array}{l}\text { Pimpinan saya memberikan nasehat yang penting } \\
\text { bagi pengembangan diri bawahan (KT4.3) }\end{array}$ & \\
\hline & & $\begin{array}{l}\text { Pimpinan saya memperlakukan bawahan sebagai } \\
\text { individu yang masing-masing memiliki kebutuhan, } \\
\text { kemampuan dan aspirasi yang berbeda (KT4.4) }\end{array}$ & \\
\hline
\end{tabular}

2. Variabel Dependen

Variabel dependen sering disebut dengan variabel terikat. Variabel terikat merupakan variabel yang dipengaruhi atau yang menjadi akibat karena adanya variabel bebas (Sugiyono, 2015). Dalam penelitian ini yang menjadi variabel dependen adalah kesiapan untuk berubah (readiness for change).

Kesiapan untuk berubah (readiness for change) dikemukakan oleh Hanpachern (1997) dalam Nugraheni (2012) sebagai sejauhmana individuindividu secara mental, psikologis atau fisik siap, atau prima untuk berpartisipasi dalam kegiatan pengembangan organisasi. Kesiapan berubah dalam penelitian ini adalah kesiapan karyawan untuk menempati kampus 4 UAD.

Indikator Kesiapan untuk Berubah Readinees For Change
Indikator Kesiapan untuk Berubah (Readiness for Change)

\begin{tabular}{|c|c|c|c|}
\hline No & Indikator & Item pertanyaan & Sumber \\
\hline \multirow[t]{3}{*}{1.} & \multirow{3}{*}{$\begin{array}{l}\text { Appropriateness } \\
\text { (Ketepatan } \\
\text { untuk } \\
\text { melakukan } \\
\text { perubahan) }\end{array}$} & $\begin{array}{l}\text { Dimasa yang akan datang, perpindahan ke } \\
\text { kampus } 4 \mathrm{UAD} \text { akan bermanfaat jika } \\
\text { dilaksanakan ( } \mathrm{RCl} .1)\end{array}$ & \multirow[t]{3}{*}{$\begin{array}{l}\text { Agustine } \\
\text { (2016) }\end{array}$} \\
\hline & & $\begin{array}{l}\text { Perpindahan ke kampus } 4 \text { UAD sesuai dengan } \\
\text { yang menjadi prioritas UAD }(\mathrm{RCl} .2)\end{array}$ & \\
\hline & & Perpindahan ke kampus 4 akan meningkatkan & \\
\hline \multirow{7}{*}{$\begin{array}{l}2 . \\
2 .\end{array}$} & & efisiensi Universitas Ahmad Dahlan (RCl.3) & \\
\hline & & $\begin{array}{l}\text { Sangat tidak masuk akal bagi karyawan UAD } \\
\text { untuk pindah ke kampus } 4 \text { (RCl.4) }\end{array}$ & \\
\hline & & $\begin{array}{l}\text { Apabila perpindahan ke kampus } 4 \\
\text { dilaksanakan, saya tidak percaya adanya } \\
\text { keuntungan apapun bagi UAD ( } \mathrm{RCl} 1.5)\end{array}$ & \\
\hline & \multirow{4}{*}{$\begin{array}{l}\text { Management } \\
\text { Support } \\
\text { (dukungan } \\
\text { manajemen). }\end{array}$} & $\begin{array}{l}\text { Pimpinan telah menganjurkan kepada } \\
\text { karyawan untuk mendukung perpindahan ke } \\
\text { kampus } 4 \text { UAD (RC2.1) }\end{array}$ & \multirow[t]{4}{*}{$\begin{array}{c}\text { Agustine } \\
\text { (2016) }\end{array}$} \\
\hline & & $\begin{array}{l}\text { Pimpinan telah memberikan semua } \\
\text { dukungannya terhadap perpindahan ke kampus } \\
4 \text { UAD (RC2.2) }\end{array}$ & \\
\hline & & $\begin{array}{l}\text { Setiap pimpinan menekankan pentingnya } \\
\text { perpindahan ke kampus } 4 \text { UAD (RC2.3) }\end{array}$ & \\
\hline & & $\begin{array}{l}\text { Saya berpikir bahwa ini hanya akan } \\
\text { menghabiskan waktu ketika para pimpinan } \\
\text { tidak menginginkan perpindahan ke kampus } 4 \\
\text { UAD dilaksanakan (RC2.4) }\end{array}$ & \\
\hline \multirow[t]{5}{*}{3.} & \multirow{5}{*}{$\begin{array}{l}\text { Change specific } \\
\text { efficacy: (rasa } \\
\text { percaya } \\
\text { terhadap } \\
\text { kemampuan } \\
\text { diri) }\end{array}$} & \begin{tabular}{|l|} 
Pengalaman masa lalu membuat saya yakin \\
bahwa saya akan mampu beradaptasi di \\
kampus 4 UAD (RC3.1) \\
\end{tabular} & \multirow[t]{3}{*}{$\begin{array}{l}\text { Agustine } \\
\text { (2016) }\end{array}$} \\
\hline & & $\begin{array}{l}\text { Saya tidak mengharapkan ada masalah dalam } \\
\text { menyesuaikan pekerjaan yang akan saya jalani } \\
\text { ketika sudah pindah ke kampus } 4 \text { UAD } \\
\text { (RC3.2) }\end{array}$ & \\
\hline & & $\begin{array}{l}\text { Saya merasa tidak akan mampu melakukan } \\
\text { beberapa tugas tambahan dengan baik, akibat } \\
\text { dari perpindahan ke kampus } 4 \text { UAD (RC3.3) }\end{array}$ & \\
\hline & & $\begin{array}{l}\text { Apabila saya yakin saya bisa, saya dapat } \\
\text { mempelajari semua yang diperlukan saat sudah } \\
\text { pindah ke kampus } 4 \text { UAD (RC3.4) }\end{array}$ & \multirow[t]{2}{*}{$\begin{array}{l}\text { Holt } \\
\text { et,al. } \\
(2007)\end{array}$} \\
\hline & & $\begin{array}{l}\text { Saya memiliki keterampilan yang dibutuhkan } \\
\text { untuk mensukseskan perpindahan ke kampus } 4 \\
\text { UAD (RC3.5) } \\
\end{array}$ & \\
\hline \multirow[t]{2}{*}{4.} & \multirow{2}{*}{\begin{tabular}{|l|} 
Personal \\
Valence \\
(Manfaat bagi \\
individu)
\end{tabular}} & $\begin{array}{l}\text { Perpindahan ke kampus } 4 \text { UAD akan memberi } \\
\text { peluang karir baru untuk saya (RC4.1) }\end{array}$ & \multirow{2}{*}{$\begin{array}{l}\text { Holt } \\
\text { et,al. } \\
(2007)\end{array}$} \\
\hline & & $\begin{array}{l}\text { Ketika perpindahan ke kampus } 4 \text { UAD } \\
\text { dilaksanakan saya dapat membayangkan } \\
\text { keuntungan finansial yang datang untuk saya } \\
\text { (RC4.2) }\end{array}$ & \\
\hline & & $\begin{array}{l}\text { Saya khawatir akan kehilangan pekerjaan saya } \\
\text { ketika perpindahan ke kampus } 4 \text { UAD } \\
\text { dilaksanakan (RC4.3) }\end{array}$ & \multirow[t]{3}{*}{$\begin{array}{c}\text { Agustine } \\
\text { (2016) }\end{array}$} \\
\hline & & $\begin{array}{l}\text { Masa depan saya dalam pekerjaan saya akan } \\
\text { terancam, karena adanya perpindahan ke } \\
\text { kampus } 4 \text { UAD (RC4.4) } \\
\end{array}$ & \\
\hline & & $\begin{array}{l}\text { Perpindahan ke kampus } 4 \text { UAD akan } \\
\text { mengganggu banyak rekan atau relasi saya } \\
\text { (RC4.5) }\end{array}$ & \\
\hline
\end{tabular}

\section{Uji Instrumen}

\section{Uji Validitas}

Uji validitas digunakan untuk mengukur sah atau valid tidaknya suatu kuesioner. Valid berarti kuesioner tersebut dapat mengukur apa yang seharusnya diukur (Sugiyono, 2015). Untuk menguji validitas dapat dilakukan dengan CFA (Confirmatory Factor Analysis). Suatu item49 kuesioner dinyatakan valid jika memiliki factor loading $\geq 0.50$ (Ghozali, 2011). 
2. Uji Reliabilitas

Reliabilitas adalah alat untuk mengukur suatu kuesioner yang merupakan indikator dari variabel atau konstruk. Kuesioner dikatakan reliabel atau handal jika kuesioner tersebut bila digunakan beberaba kali untuk mengukur objek yang sama, akan menghasilkan data yang sama (Sugiyono, 2015). Suatu item dikatakan reliabel, jika nilai Cronbach Alpha $>0,60$ (Ghozali, 2011).

\section{Teknik Analisis Data}

1. Analisis Regresi

Dalam penelitian ini, peneliti menggunakan analisis regresi berganda. Analisis regresi berganda digunakan untuk mengetahui pengaruh variabel independen terhadap variabel dependen, dengan rumus sebagai berikut:

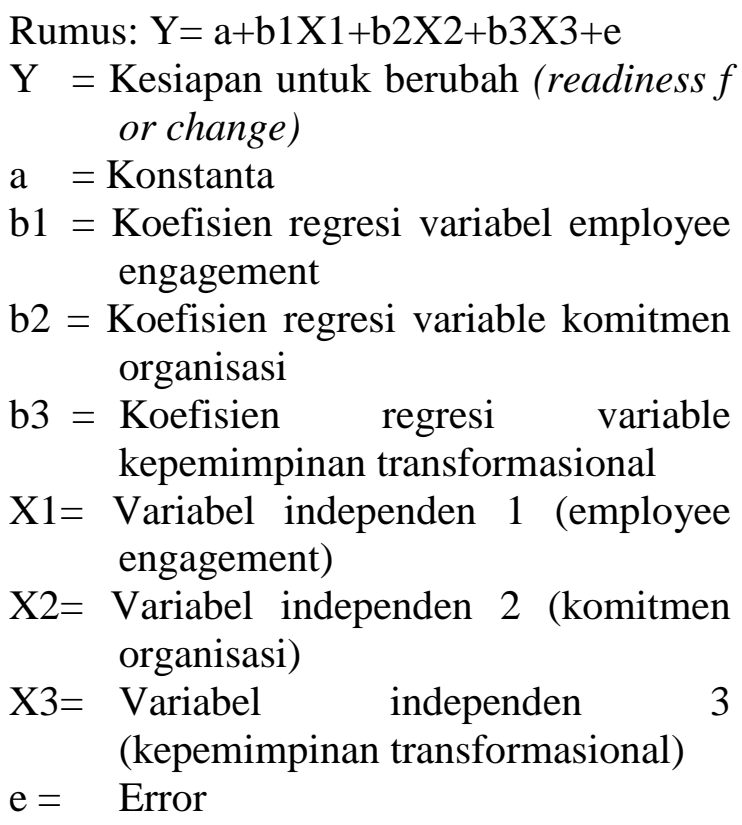

\section{Uji Hipotesis}

\section{Uji Parsial (Uji T)}

Uji t (uji parsial) digunakan untuk mengetahui signifikan atau tidaknya pengaruh variabel independen terhadap variabel dependen secara individual. Hasil Uji $t$ dapat dilihat berdasarkan signifikannya:

Jika tingkat signifikansi $<0,05$, maka hipotesis diterima.
Jika tingkat signifikansi $>0,05$, maka hipotesis ditolak.

\section{Uji Simultan (Uji F)}

Uji F (uji parsial) digunakan untuk mengetahui pengaruh variabel independen terhadap variabel dependen secara bersama-sama (parsial). Untuk mengetahui signifikan atau tidaknya pengaruh variabel bebas terhadap variabel terikat secara simultan maka digunakan $\alpha$ sebesar 5\%. Jika sig $>\alpha(0,05)$, hipotesis ditolak. Jika $\operatorname{sig}<\alpha(0,05)$, hipotesis diterima.

\section{Uji Koefisien Determinasi}

Koefisien digunakan untuk mengukur seberapa jauh variabel independen dapat menerangkan variabel dependennya. Nilai koefisien determinasi adalah antara nol dan satu. Nilai R2 semakin baik jika mendekati satu yang berarti semakin besar kontribusi varabel-variabel independen dalam menjelaskan variable dependennya.

\section{HASIL PENELITIAN DAN PEMBAHASAN}

\section{Hasil Analisis Responden}

Karakteristik Responden

\begin{tabular}{|c|c|c|c|}
\hline Keterangan & & $\begin{array}{c}\text { Frekuensi } \\
\text { (orang) }\end{array}$ & $\begin{array}{c}\text { Persentase } \\
(\%)\end{array}$ \\
\hline \multirow{3}{*}{ Jenis Kelamin } & Laki-laki & 69 & 67 \\
\hline & Perempuan & 34 & 33 \\
\hline & Jumlah & 103 & $100 \%$ \\
\hline \multirow{3}{*}{$\begin{array}{l}\text { Status } \\
\text { Kepegawaian }\end{array}$} & Pegawai Tetap & 103 & 100 \\
\hline & Pegawai Kontrak & 0 & 0 \\
\hline & Jumlah & 103 & $100 \%$ \\
\hline \multirow{3}{*}{$\begin{array}{l}\text { Sudah pindah } \\
\text { atau belum ke } \\
\text { kampus } 4 \text { UAD }\end{array}$} & Sudah & 0 & 0 \\
\hline & Belum & 103 & 100 \\
\hline & Jumlah & 103 & $100 \%$ \\
\hline \multirow{6}{*}{ Masa Kerja } & $<1$ tahun & 0 & 0 \\
\hline & $1-5$ tahun & 23 & 22,3 \\
\hline & 6-10 tahun & 11 & 10,7 \\
\hline & $>10$ tahun & 62 & 60,2 \\
\hline & Lainnya & 7 & 6,8 \\
\hline & Jumlah & 103 & $100 \%$ \\
\hline
\end{tabular}

Berdasarkan pada tabel 4.2 tersebut dapat diketahui karakteristik responden yaitu:

1. Responden yang berjenis kelamin lakilaki sebanyak 69 orang atau $67 \%$ dari total responden sebanyak 103 orang.

2. Responden yang berjenis kelamin perempuan sebanyak 34 orang atau 33\% dari total responden sebanyak 103 orang. 
3. Responden dengan status pegawai tetap sebanyak 103 orang atau $100 \%$ dari total responden sebanyak 103 orang.

4. Responden dengan status pegawai kontrak sebanyak 0 orang atau $0 \%$ dari total responden sebanyak 103 orang.

5. Responden yang belum pindah ke kampus 4 UAD sebanyak 103 orang atau $100 \%$ dari total responden sebanyak 103 orang.

6. Responden yang sudah pindah ke kampus 4 UAD sebanyak 0 orang atau 0 $\%$ dari total responden sebanyak 103 orang.

7. Responden yang mempunyai masa kerja $<1$ tahun sebanyak 0 orang atau $0 \%$ dari total responden sebanyak 103 orang.

8. Responden yang mempunyai masa kerja 1-5 tahun sebanyak 23 orang atau 22,3 $\%$ dari total responden sebanyak 103 orang.

9. Responden yang mempunyai masa kerja 6-10 tahun sebanyak 11 orang atau 10,7 $\%$ dari total responden sebanyak 103 orang.

10.Responden yang mempunyai masa kerja $>10$ tahun sebanyak 62 orang atau $60,2 \%$ dari total responden sebanyak 103 orang.

11.Responden yang mempunyai masa kerja lainnya (diatas 15 tahun) sebanyak 7 orang atau $6,8 \%$ dari total responden sebanyak 103 orang.

\section{Hasil Penelitian}

1. Hasil Uji Validitas

Kesiapan untuk Berubah (Readiness for Change) $\left(\mathrm{X}_{1}\right)$

Berdasarkan uji validitas dengan menggunakan SPSS versi 20 dapat diketahui bahwa dari 19 item pertanyaan, 11 item dinyatakan valid yaitu $\mathrm{RC} 1.1$, $\mathrm{RC} 1.2, \mathrm{RC} 1.3, \mathrm{RC} 1.4, \mathrm{RC} 1.5, \mathrm{RC} 2.1$, $\mathrm{RC} 2.2, \mathrm{RC} 3.1, \mathrm{RC} 3.4, \mathrm{RC} 3.5, \mathrm{RC} 4.1$, sedangkan 8 item tidak valid yaitu RC2.3, RC2.4, RC3.2, RC3.3, RC4.2 RC4.3, $\mathrm{RC} 4.4$, dan RC4.5 karena memiliki nilai loading factor $<0,50$. Uraian uji validitas item kesiapan untuk berubah (readiness for change) tahap pertama dapat dilihat pada tabel 4.3:

Hasil Uji Validitas Kesiapan untuk Berubah (Readiness for Change)

(Tahap Pertama)

\begin{tabular}{|c|c|c|}
\hline Item & Loading Factor & Kriteria \\
\hline RC1.1 & 0,796 & Valid \\
\hline RC1.2 & 0,599 & Valid \\
\hline RC1.3 & 0,624 & Valid \\
\hline RC1.4 & 0,721 & Valid \\
\hline RC1.5 & 0,726 & Valid \\
\hline RC2.1 & 0,528 & Valid \\
\hline RC2.2 & 0,697 & Valid \\
\hline RC2.3 & 0,432 & Tidak Valid \\
\hline RC2.4 & $-0,022$ & Tidak Valid \\
\hline RC3.1 & 0,590 & Valid \\
\hline RC3.2 & $-0,469$ & Tidak Valid \\
\hline RC3.3 & 0,219 & Tidak Valid \\
\hline RC3.4 & 0,825 & Valid \\
\hline RC3.5 & 0,745 & Valid \\
\hline RC4.1 & 0,583 & Valid \\
\hline RC4.2 & $-0,108$ & Tidak Valid \\
\hline RC4.3 & -0.745 & Tidak Valid \\
\hline RC4.4 & $-0,153$ & Tidak Valid \\
\hline RC4.5 & $-0,379$ & Tidak Valid \\
\hline Sumber: Data Primer, diolah (2018)
\end{tabular}

Setelah ditemukan item yang tidak valid pada uji validitas tahap pertama, kemudian semua item diuji kembali menggunakan SPSS versi 20 sebanyak 8 tahap dengan cara menghilangkan atau membuang satu per satu item dengan nilai loading factor terkecil (RC4.3, RC3.2, RC4.5, RC4.4, RC2.4, RC4.2, RC3.3, $\mathrm{RC} 2.3)$ sampai ditemukan semua item yang mengukur kesiapan untuk berubah (readiness for change) valid semua. Uraian uji validitas item kesiapan untuk berubah (readiness for change) tahap terakhir dapat dilihat pada tabel 4.4:

Hasil Uji Validitas Kesiapan untuk Berubah (Readiness for Change) (Tahap Terakhir)

\begin{tabular}{|c|c|c|}
\hline Item & Loading Factor & Kriteria \\
\hline RC1.1 & 0,759 & Valid \\
\hline RC1.2 & 0,682 & Valid \\
\hline RC1.3 & 0,644 & Valid \\
\hline RC1.4 & 0,635 & Valid \\
\hline RC1.5 & 0,729 & Valid \\
\hline RC2.1 & 0,604 & Valid \\
\hline RC2.2 & 0,647 & Valid \\
\hline RC3.1 & 0,676 & Valid \\
\hline RC3.4 & 0,812 & Valid \\
\hline RC3.5 & 0,767 & Valid \\
\hline RC4.1 & 0,656 & Valid \\
\hline
\end{tabular}

\section{Employee Engagement $\left(\mathrm{X}_{2}\right)$}

Berdasarkan uji validitas dengan menggunakan SPSS versi 20 dapat diketahui bahwa dari 14 item pertanyaan, 8 item dinyatakan valid yaitu EE1.1, EE1.2, EE1.3, EE1.4, EE2.1, EE2.2, EE2.5, dan EE3.5 dan 6 item tidak valid karena memiliki nilai loading factor $<0,50$ yaitu EE2.3, EE2.4, EE3.1, EE3.2, EE3.3, dan 
EE3.4. Uraian uji validitas tahap pertama item employee engagement dapat dilihat pada tabel 4.5.

Selanjutnya dilakukan uji validitas kembali menggunakan SPSS versi 20 dengan cara menghilangkan atau membuang satu per satu item dengan nilai loading factor terkecil (EE3.2, EE3.3, EE3.1, EE2.4) sebanyak 4 tahap sampai semua item employee engagement valid. Uraian uji validitas tahap terakhir item employee engagement dapat dilihat pada tabel 4.6:

Hasil Uji Validitas Employee Engagement

(Tahap Pertama)

\begin{tabular}{|c|c|c|}
\hline Item & Loading Factor & Kriteria \\
\hline EE1.1 & 0,736 & Valid \\
\hline EE1.2 & 0,671 & Valid \\
\hline EE1.3 & 0,632 & Valid \\
\hline EE1.4 & 0,748 & Valid \\
\hline EE2.1 & 0,740 & Valid \\
\hline EE2.2 & 0,692 & Valid \\
\hline EE2.3 & 0,494 & Tidak Valid \\
\hline EE2.4 & 0,473 & Tidak Valid \\
\hline EE2.5 & 0,577 & Valid \\
\hline EE3.1 & 0,424 & Tidak Valid \\
\hline EE3.2 & 0,397 & Tidak Valid \\
\hline EE3.3 & 0,432 & Tidak Valid \\
\hline EE3.4 & 0,459 & Tidak Valid \\
\hline EE3.5 & 0,532 & Valid \\
\hline
\end{tabular}

Sumber: Data Primer, diolah (2018)

Hasil Uji Validitas Employee Engagement

(Tahap Terakhir)

\begin{tabular}{|c|c|c|}
\hline Item & Loading Factor & Kriteria \\
\hline EE1.1 & 0,709 & Valid \\
\hline EE1.2 & 0,712 & Valid \\
\hline EE1.3 & 0,621 & Valid \\
\hline EE1.4 & 0,746 & Valid \\
\hline EE2.1 & 0,737 & Valid \\
\hline EE2.2 & 0,740 & Valid \\
\hline EE2.3 & 0,567 & Valid \\
\hline EE2.5 & 0,514 & Valid \\
\hline EE3.4 & 0,532 & Valid \\
\hline EE3.5 & 0,636 & Valid \\
\hline
\end{tabular}

Sumber: Data Primer, diolah (2018)

Komitmen Organisasi $\left(\mathrm{X}_{3}\right)$

Berdasarkan uji validitas dengan menggunakan SPSS versi 20 dapat diketahui bahwa dari 14 item pertanyaan, 9 item dinyatakan valid yaitu KO1.1, KO1.3, $\mathrm{KO} 1.5, \mathrm{KO} 2.2, \mathrm{KO} 2.3, \mathrm{KO} 3.1, \mathrm{KO} 3.2$, KO3.3 dan KO3.4. Selain itu, terdapat 5 item tidak valid karena memiliki nilai loading factor < 0,50 yaitu KO1.2, KO1.4, $\mathrm{KO} 2.1, \mathrm{KO} 2.4$, dan KO3.5. Uraian uji validitas tahap pertama item komitmen organisasi dapat dilihat pada tabel 4.7.
Selanjutnya dilakukan uji validitas kembali menggunakan SPSS versi 20 sebanyak 6 tahap dengan cara menghilangkan atau membuang satu per satu item dengan nilai loading factor terkecil (KO2.4, KO3.5, KO2.1, KO1.4, KO1,5, KO1.2) sampai semua item komitmen organisasi valid. Uraian uji validitas tahap terakhir item komitmen organisasi dapat dilihat pada tabel 4.8.

Hasil Uji Validitas Komitmen Organisasi

(Tahap Pertama)

\begin{tabular}{|c|c|c|}
\hline Item & Loading Factor & Kriteria \\
\hline KO1.1 & 0,693 & Valid \\
\hline KO1.2 & 0,454 & Tidak Valid \\
\hline KO1.3 & 0,607 & Valid \\
\hline KO1.4 & 0,353 & Tidak Valid \\
\hline KO1.5 & 0,500 & Valid \\
\hline KO2.1 & 0,183 & Tidak Valid \\
\hline KO2.2 & 0,680 & Valid \\
\hline KO2.3 & 0,547 & Valid \\
\hline KO2.4 & $-0,501$ & Tidak Valid \\
\hline KO3.1 & 0,750 & Valid \\
\hline KO3.2 & 0,659 & Valid \\
\hline KO3.3 & 0,751 & Valid \\
\hline KO3.4 & 0,880 & Valid \\
\hline KO3.5 & $-0,439$ & Tidak Valid \\
\hline Sumber: Data Primer
\end{tabular}

Sumber: Data Primer, diolah (2018)

Hasil Uji Validitas Komitmen Organisasi

(Tahap Terakhir)

\begin{tabular}{|c|c|c|}
\hline Item & Loading Factor & Kriteria \\
\hline KO1.1 & 0,743 & Valid \\
\hline KO1.3 & 0,572 & Valid \\
\hline KO2.2 & 0,724 & Valid \\
\hline KO2.3 & 0,582 & Valid \\
\hline KO3.1 & 0,769 & Valid \\
\hline KO3.2 & 0,653 & Valid \\
\hline KO3.3 & 0,724 & Valid \\
\hline KO3.4 & 0,922 & Valid \\
\hline
\end{tabular}

Sumber: Data Primer, diolah (2018)

Kepemimpinan Transformasional $\left(\mathrm{X}_{4}\right)$

Berdasarkan uji validitas dengan menggunakan SPSS versi20 dapat diketahui bahwa dari 17 item pertanyaan, 15 item dinyatakan valid yaitu KT1.1, KT1.2, KT1.4, KT2.1, KT2.2, KT2.4, KT2.5, KT3.1, KT3.2, KT3.3, КT3.4, KT4.1, KT4.2, KT4.3, KT4.4, sedangkan 2 item dinyatakan tidak valid karena memiliki nilai loading factor $<0,50$ yaitu KT1.3 dan KT2.3. Uraian uji validitas tahap pertama item kepemimpinan transformasional dapat dilihat pada tabel 4.9 .

Untuk menghilangkan item yang tidak valid, kemudian dilakukan uji validitas kembali menggunakan SPSS 
versi 20 sebanyak 2 tahap dengan dengan cara menghilangkan atau membuang satu per satu item dengan nilai loading factor terkecil (KT1.3, KT2.3). Uraian uji validitas tahap terakhir item kepemimpinan transformasional dapat dilihat pada tabel 4.10.

Hasil Uji Validitas Kepemimpinan Transformasional

(Tahap Pertama)

\begin{tabular}{|c|c|c|}
\hline Item & Loading Factor & Kriteria \\
\hline KT1.1 & 0,816 & Valid \\
\hline KT1.2 & 0,833 & Valid \\
\hline KT1.3 & 0,287 & Tidak Valid \\
\hline KT1.4 & 0,648 & Valid \\
\hline KT2.1 & 0,853 & Valid \\
\hline KT2.2 & 0,755 & Valid \\
\hline KT2.3 & 0,448 & Tidak Valid \\
\hline KT2.4 & 0,587 & Valid \\
\hline KT2.5 & 0,844 & Valid \\
\hline KT3.1 & 0,738 & Valid \\
\hline KT3.2 & 0,842 & Valid \\
\hline KT3.3 & 0,835 & Valid \\
\hline KT3.4 & 0,785 & Valid \\
\hline KT4.1 & 0,662 & Valid \\
\hline KT4.2 & 0,776 & Valid \\
\hline KT4.3 & 0,834 & Valid \\
\hline KT4.4 & 0,543 & Valid \\
\hline
\end{tabular}

Sumber: Data Primer, diolah (2018)

Hasil Uji Validitas Kepemimpinan Transformasional

(Tahap Terakhir)

\begin{tabular}{|c|c|c|}
\hline Item & Loading Factor & Kriteria \\
\hline KT1.1 & 0,822 & Valid \\
\hline KT1.2 & 0,833 & Valid \\
\hline KT1.4 & 0,640 & Valid \\
\hline KT2.1 & 0,858 & Valid \\
\hline KT2.2 & 0,769 & Valid \\
\hline KT2.4 & 0,585 & Valid \\
\hline KT2.5 & 0,854 & Valid \\
\hline KT3.1 & 0,729 & Valid \\
\hline KT3.2 & 0,844 & Valid \\
\hline KT3.3 & 0,838 & Valid \\
\hline KT3.4 & 0,779 & Valid \\
\hline KT4.1 & 0,656 & Valid \\
\hline KT4.2 & 0,781 & Valid \\
\hline KT4.3 & 0,836 & Valid \\
\hline KT4.4 & 0,532 & Valid \\
\hline
\end{tabular}

Sumber: Data Primer, diolah (2018)

Sehingga, dari 64 butir pernyataan pada keseluruhan variabel hanya memiliki 44 butir pernyataan yang dapat dikatakan valid sesuai standar yang memiliki nilai factor loading $\geq 0,50$ dan tidak terdapat nilai negatif seperti pada tabel 4.11:
Hasil Uji Validitas Semua Variabel

\begin{tabular}{|c|c|c|c|c|c|}
\hline Item & $\begin{array}{c}\text { Kesiapan } \\
\text { untuk } \\
\text { Berubah } \\
\text { (Readiness } \\
\text { for Change) }\end{array}$ & $\begin{array}{c}\text { Employee } \\
\text { Engagement }\end{array}$ & $\begin{array}{c}\text { Komitmen } \\
\text { Organisasi }\end{array}$ & $\begin{array}{c}\text { Kepemimpi } \\
\text { nan } \\
\text { Transform } \\
\text { asional }\end{array}$ & Keterangan \\
\hline RC1.1 & 0,759 & & & & Valid \\
\hline RC1.2 & 0,682 & & & & Valid \\
\hline RC1.3 & 0,644 & & & & Valid \\
\hline RC1.4 & 0,635 & & & & Valid \\
\hline RC1.5 & 0,729 & & & & Valid \\
\hline RC2.1 & 0,604 & & & & Valid \\
\hline RC2.2 & 0,647 & & & & Valid \\
\hline RC3.1 & 0,676 & & & & Valid \\
\hline RC33.4 & 0,812 & & & & Valid \\
\hline RC3.5 & 0,767 & & & & Valid \\
\hline RC4.1 & 0,656 & & & & Valid \\
\hline EE1.1 & & 0,709 & & & Valid \\
\hline EE1.2 & & 0,712 & & & Valid \\
\hline EE1.3 & & 0,621 & & & Valid \\
\hline EE1.4 & & 0,746 & & & Valid \\
\hline EE2.1 & & 0,737 & & & Valid \\
\hline EE2.2 & & 0,740 & & & Valid \\
\hline EE2.3 & & 0,567 & & & Valid \\
\hline EE2.5 & & 0,514 & & & Valid \\
\hline EE3.4 & & 0,532 & & & Valid \\
\hline EE3.5 & & 0,636 & & & Valid \\
\hline KO1.1 & & & 0,743 & & Valid \\
\hline KO1.3 & & & 0,572 & & Valid \\
\hline KO2.2 & & & 0,724 & & Valid \\
\hline KO2.3 & & & 0,582 & & Valid \\
\hline KO3.1 & & & 0,769 & & Valid \\
\hline KO3.2 & & & 0,653 & & Valid \\
\hline KO3.3 & & & 0,724 & & Valid \\
\hline KO3.4 & & & 0,922 & & Valid \\
\hline KT1.1 & 0,822 & & & 0,822 & Valid \\
\hline KT1.2 & 0,833 & & & 0,833 & Valid \\
\hline KT1.4 & 0,640 & & & 0,640 & Valid \\
\hline KT2.1 & 0,858 & & & 0,858 & Valid \\
\hline KT2.2 & 0,769 & & & 0,769 & Valid \\
\hline KT2.4 & 0,585 & & & 0,585 & Valid \\
\hline KT2.5 & 0,854 & & & 0,854 & Valid \\
\hline KT3.1 & 0,729 & & & 0,729 & Valid \\
\hline KT3.2 & 0,844 & & & 0,844 & Valid \\
\hline KT3.3 & 0,838 & & & 0,838 & Valid \\
\hline KT3.4 & 0,779 & & & 0,779 & Valid \\
\hline KT4.1 & 0,656 & & & 0,656 & Valid \\
\hline KT4.2 & 0,781 & & & Valid \\
\hline KT4.3 & 0,836 & & & Valid \\
\hline KT4.4 & 0,532 & & & & \\
\hline Sumber: Data Primer, diolah $(2018)$ & & & \\
\hline
\end{tabular}

\section{Hasil Uji Reliabilitas}

Suatu kuesioner dikatakan reliabel atau handal jika jawaban seseorang terhadap pernyataan adalah konsisten atau stabil dari waktu ke waktu. Uji reliabilitas yang digunakan dalam penelitian ini yaitu uji statistik Cronbach Alpha. Suatu kuesioner dinyatakan reliabel jika nilai cronbach alpha > 0,60. Berdasarkan output SPSS versi 20 diperoleh nilai Cronbach's Alpha untuk variabel kesiapan untuk berubah (readiness for change), employee engagement, komitmen organisasi dan kepemimpinan transformasional sebagai berikut:

Hasil Uji Reliabilitas
\begin{tabular}{|c|c|c|}
\hline Variabel & $\begin{array}{c}\text { Cronbach's } \\
\text { Alpha }\end{array}$ & Keterangan \\
\hline $\begin{array}{c}\text { Kesiapan untuk Berubah (Readiness for } \\
\text { Change) }(\mathrm{Y})\end{array}$ & 0,887 & Reliabel \\
\hline Employee Engagement $\left(\mathrm{X}_{1)}\right.$ & 0,843 & Reliabel \\
\hline Komitmen Organisasi $\left(\mathrm{X}_{2}\right)$ & 0,848 & Reliabel \\
\hline Kepemimpinan Transformasional $\left(\mathrm{X}_{3)}\right.$ & 0,945 & Reliabel \\
\hline Sumber: Data Primer, diolah (2018)
\end{tabular}

Sumber: Data Primer, diolah (2018) 
Berdasarkan tabel 4.12 dapat diketahui bahwa semua variabel dinyatakan reliabel karena nilai Cronbach's Alpha tiap variabel > 0,60.

3. Hasil Uji Regresi Linier Berganda

Analisis regresi linear berganda dilakukan untuk menganalisis kesiapan untuk berubah (readiness for change) yang dipengaruhi oleh employee engagement, komitmen organisasi dan kepemimpinan transformasional. Berdasarkan uji regresi berganda diperoleh hasil sebagai berikut:

Hasil Uji Regresi Linear Berganda
\begin{tabular}{|c|c|c|}
\hline Model & B & Sig. \\
\hline (Constant) & 1,095 & 0,022 \\
EE $\left(\mathrm{X}_{1}\right)$ & 0,200 & 0,244 \\
KO $\left(\mathrm{X}_{2}\right)$ & 0,392 & 0,000 \\
KT $\left(\mathrm{X}_{3}\right)$ & 0,041 & 0,747 \\
\hline
\end{tabular}
Sumber: Data Primer, diolah (2018)

Berdasarkan hasil perhitungan dengan menggunakan program IBM SPSS Statistics 20 dapat diketahui persamaan regresi linear berganda yaitu sebagai berikut:

$\mathrm{Y}=1,095+0,200 \mathrm{X} 1+0,392 \mathrm{X} 2$ $+0,041 \mathrm{X} 3+\mathrm{e}$

Dari hasil persamaan regresi linear berganda tersebut, dapat diinterpretasikan sebagai berikut:

1) Koefisien regresi kesiapan untuk berubah (readiness for change) (Y) adalah 1,095 merupakan nilai konstanta, jika nilai X1, X2, X3 dianggap 0 , maka kesiapan untuk berubah (readiness for change) nilainya sebesar $1,095.65$

2) Koefisien regresi employee engagement (X1) adalah 0,200 yang artinya setiap kenaikan nilai employee engagement sebesar 1 satuan dan nilai dari variabel lainnya tetap (konstan), maka kesiapan untuk berubah (readiness for change) akan meningkat sebesar 0,200 satuan.

3) Koefisien regresi komitmen organisasi (X2) adalah 0,392 yang artinya setiap kenaikan nilai komitmen organisasi sebesar 1 satuan dan nilai dari variabel lainnya tetap (konstan), maka kesiapan untuk berubah (readiness for change) akan meningkat sebesar 0,392 satuan.

4) Koefisien regresi kepemimpinan transformasional (X3) adalah 0,041 yang artinya setiap kenaikan nilai kepemimpinan transformasional sebesar 1 satuan dan nilai dari variabel lainnya tetap (konstan), maka kesiapan untuk berubah (readiness for change) akan meningkat sebesar 0,041 satuan.

\section{Hasil Uji Parsial (Uji T)}

Uji signifikansi parsial atau individual digunakan untuk menguji pengaruh employee engagement (X1), komitmen organisasi (X2) dan kepemimpinan transformasional (X3) terhadap kesiapan untuk berubah (readiness for change) (Y).

\begin{tabular}{|c|c|}
\hline Hasil Uji Signifikansi P & \\
\hline \multirow{2}{*}{ Variabel } & Hasil Uji \\
\hline & Signifikansi \\
\hline Employee Engagement & 0,244 \\
\hline Komitmen Organisasi & 0,000 \\
\hline Kepemimpinan Transformasional & 0,747 \\
\hline
\end{tabular}

Berdasarkan tabel 4.14, maka hasil uji $\mathrm{t}$ pada penelitian ini dapat dijelaskan sebagai berikut:

a) Variabel Employee Engagement

Berdasarkan nilai signifikansi pada tabel 4.14, diketahui bahwa nilai signifikansi yang diperoleh sebesar 0,244 , hal ini menunjukkan bahwa nilai signifikansi 0,244 >0,05, maka dapat disimpulkan bahwa $\mathrm{H} 1$ ditolak yang berarti employee engagement (X1) tidak berpengaruh terhadap kesiapan untuk berubah (readiness for change) (Y) karyawan Universitas Ahmad Dahlan.

b) Variabel Komitmen Organisasi

Berdasarkan dari nilai signifikansi pada tabel 4.14, diketahui besarnya nilai signifikansi yang diperoleh sebesar 0,000, hal ini menunjukkan bahwa nilai signifikansi $0,000<0,05$, maka dapat 
disimpulkan bahwa $\mathrm{H} 2$ diterima yang berarti komitmen organisasi berpengaruh terhadap kesiapan untuk berubah (readiness for change) (Y) karyawan Universitas Ahmad Dahlan.

c) Kepemimpinan Transformasional

Berdasarkan nilai signifikansi pada tabel 4.14, diketahui besarnya nilai signifikansi yang diperoleh sebesar 0,747, hal ini menunjukkan bahwa nilai signifikansi $0,747>0,05$, maka dapat disimpulkan bahwa $\mathrm{H} 3$ ditolak yang berarti kepemimpinan transformasional tidak berpengaruh terhadap kesiapan untuk berubah (readiness for change) (Y) karyawan Universitas Ahmad Dahlan.

\section{Hasil Uji Simultan (Uji F)}

Uji $F$ menunjukkan pengaruh semua variabel independen employee engagement (X1), komitmen organisasi (X2) dan kepemimpinan transformasional (X3) secara simultan terhadap variabel dependen kesiapan untuk berubah (readiness for change) (Y)

\begin{tabular}{|c|c|}
\hline \multicolumn{2}{|c|}{ Uji F } \\
\hline F & Sig. \\
\hline 11,491 & $0,000^{b}$ \\
\hline
\end{tabular}

Berdasarkan hasil uji simultan pada tabel 4.15 diketahui bahwa $\mathrm{F}$ hitung sebesar 11,491 dan nilai signifikansi sebesar $0,000<0,05$ sehingga dapat disimpulkan bahwa employee engagement (X1), komitmen organisasi (X2) dan kepemimpinan transformasional (X3) berpengaruh secara simultan terhadap variabel dependen kesiapan untuk berubah (readiness for change) (Y).

\section{Hasil Uji Koefisien Determinasi}

Koefisien determinasi bertujuan untuk mengetahui seberapa besar konstribusi variabel independen employee engagement (X1), komitmen organisasi (X2) dan kepemimpinan transformasional (X3) dapat menjelaskan variabel dependen kesiapan untuk berubah (readiness for change) (Y). Berikut ini adalah hasil analisis uji koefisien determinasi:

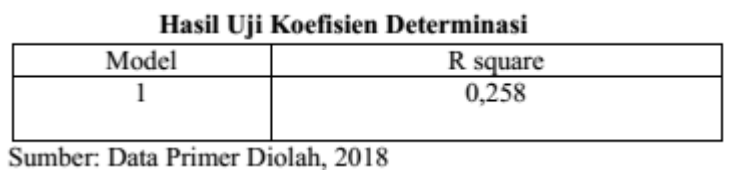

Berdasarkan tabel 4.16 diketahui bahwa nilai R2 sebesar 0,258. Hal ini dapat diartikan bahwa variabel independen employee engagement (X1), komitmen organisasi (X2) dan kepemimpinan transformasional (X3) dapat menjelaskan variabel dependen kesiapan untuk berubah (readiness for change) (Y) sebesar 25,8\%, sedangkan sisanya $74,2 \%$ dijelaskan oleh variabel lain yang tidak diteliti.

\section{Pembahasan}

Berdasarkan hasil analisis, maka pembahasan mengenai hasil penelitian sebagai berikut:

1. Pernyataan hipotesis pertama bahwa variabel employee engagement (X1) berpengaruh terhadap kesiapan untuk berubah (readiness for change) (Y) karyawan Universitas Ahmad Dahlan tidak terbukti dalam penelitian ini. Hal ini ditunjukkan dengan nilai signifikansi sebesar $0,244>0,05$. Berdasarkan hal tersebut peneliti dapat menyimpulkan ada faktor lain yang berpengaruh terhadap kesiapan untuk berubah karyawan universitas Ahmad Dahlan. Bila dilihat dari karakteristik responden yang sebagian besar memiliki masa kerja diatas 10 tahun serta jawaban responden pada itemitem pertanyan yang diajukan peneliti maka peneliti menyimpulkan bahwa karyawan Universitas Ahmad Dahlan memiliki tanggung jawab yang sangat besar terhadap pekerjaan, komitmen kuat untuk tetap mempertahankan keanggotaan dalam organisasi serta komitmen kuat dalam pekerjaannya, selain itu karyawan Universitas Ahmad Dahlan memiliki anggapan bahwa 
menyukai dan rela mengorbankan sumber daya baik berupa pikiran maupun tenaga pada pekerjaan mereka adalah sebuah kewajaran. Hal ini menunjukkan bahwa faktor yang berpengaruh terhadap kesiapan karyawan untuk berubah lebih kepada faktor lain seperti komitmen organisasi dan variabel lain yang tidak diteliti dalam penelitian ini. Dengan demikian dapat disimpulkan bahwa employee engagement tidak berpengaruh terhadap kesiapan untuk berubah (readiness for change) karyawan Universitas Ahmad Dahlan.

2. Pernyataan hipotesis kedua bahwa variabel komitmen organisasi (X2) berpengaruh terhadap kesiapan untuk berubah (readiness for change) (Y) karyawan Universitas Ahmad Dahlan terbukti dalam penelitian ini. Hal ini ditunjukkan dengan nilai signifikansi $0,000<0,05$. Dari hasil tersebut dapat dibuktikan bahwa komitmen organisasi berpengaruh terhadap kesiapan untuk berubah (readiness for change) karyawan Universitas Ahmad Dahlan. Dengan demikian dapat diambil kesimpulan bahwa semakin tinggi komitmen karyawan UAD maka semakin tinggi kesiapan untuk berubah (readiness for change) pada karyawan Universitas Ahmad Dahlan Hasil penelitian ini sesuai dengan penelitian Periantalo dan Mansoer (2008) yang membuktikan bahwa komitmen organisasi berpengaruh terhadap kesiapan untuk berubah (readiness for change).

3. Pernyataan hipotesis ketiga bahwa variabel kepemimpinan transformasional (X3) berpengaruh terhadap kesiapan untuk berubah (readiness for change) (Y) karyawan Universitas Ahmad Dahlan tidak terbukti dalam penelitian ini. Hal ini ditunjukkan dengan nilai signifikansi sebesar 0,747 >0,05. Bila melihat dari karakteristik karyawan yang sebagian besar memiliki masa kerja diatas 10 tahun serta jawaban responden pada item-item pertanyan yang diajukan peneliti, maka Universitas Ahmad Dahlan memiliki karyawan yang telah berpengalaman dan mandiri dalam pekerjaannya. Pemimpin lebih bersifat mengarahkan jika diperlukan. Selain itu ada kerancuan tentang persepsi pemimpin oleh para karyawan sehingga ada kemungkinan pemimpin setiap unit di UAD ikut mengisi kuesioner, hal tersebut dapat menyebabkan penilaian variabel kepemimpinan transformasional menjadi bias karena pemimpin menilai dirinya sendiri dan hasil yang diperoleh menjadi tidak signifikan. Dengan demikian dapat disimpulkan bahwa kepemimpinan transformasional tidak berpengaruh terhadap kesiapan untuk berubah (readiness for change) karyawan Universitas Ahmad Dahlan.

4. Pernyataan hipotesis keempat bahwa employee engagement, komitmen organisasi, dan kepemimpinan transformasional berpengaruh secara simultan terhadap kesiapan untuk berubah (readiness for change) pada karyawan Universitas Ahmad Dahlan Yogyakarta terbukti dalam penelitian ini. Hal ini ditunjukkan dengan nilai signifikansi $0,000<0,05$, dengan demikian dapat disimpulkan bahwa employee engagement (X1), komitmen organisasi (X2) dan kepemimpinan transformasional (X3) berpengaruh secara simultan terhadap kesiapan untuk berubah (readiness for change) (Y) karyawan Universitas Ahmad Dahlan Yogyakarta.

\section{KESIMPULAN DAN SARAN}

\section{Kesimpulan}

Berdasarkan hasil penelitian, maka peneliti dapat menarik kesimpulan sebagai berikut:

1. Employee engagement tidak berpengaruh terhadap kesiapan untuk 
berubah (readiness for change) karyawan Universitas Ahmad Dahlan.

2. Komitmen organisasi berpengaruh terhadap kesiapan untuk berubah (readiness for change) karyawan Universitas Ahmad Dahlan.

3. Kepemimpinan transformasional tidak berpengaruh terhadap kesiapan untuk berubah (readiness for change) karyawan Universitas Ahmad Dahlan.

4. Employee engagement, komitmen organisasi, dan kepemimpinan transformasional berpengaruh secara simultan terhadap kesiapan untuk berubah (readiness for change) pada karyawan Universitas Ahmad Dahlan Yogyakart

\section{Saran}

Berdasarkan hasil pembahasan dan kesimpulan yang diperoleh, maka saran dari penelitian ini adalah:

1. Universitas Ahmad Dahlan Yogyakarta sebaiknya memberi perhatian khusus dan melakukan beberapa upaya untuk mempertahankan dan meningkatkan serta menumbuhkan komitmen organisasi pada karyawan UAD karena untuk kedepannya Universitas Ahmad Dahlan akan menghadapi banyak perubahan, dan komitmen organisasi karyawan memberi banyak keuntungan diantaranya komitmen organisasi karyawan UAD berpengaruh terhadap kesiapan karyawan menghadapi perubahan.

2. Peneliti selanjutnya hendaknya menambah variabel lain yang diteliti. 74

3. Penelitian selanjutnya hendaknya lebih hati-hati dalam menyusun dan menyebarkan kuesioner sehingga kuesioner yang disebar benar-benar diisi oleh objek penelitian yang dituju.

4. Penelitian selanjutnya hendaknya menguji model penelitian ini pada konteks pekerjaan atau profesi yang berbeda.

\section{DAFTAR PUSTAKA}

Agustine, Francellin. 2016. Hubungan Komitmen Organisasi dengan Kesiapan untuk Berubah (Readiness for Change) Karyawan. Skripsi. Malang: Universitas Muhammadiyah Malang

Akbar, Muhammad Rizza. 2013. "Pengaruh Budaya Organisasi terhadap Employee Engagement (Studi pada Karyawan PT. Primatexco Indonesia di Batang)" Journal of Social and Industrial Psychology (Oktober), hal. 10-18

Daft, Richard L. 2012. Era Baru Manajemen. Jakarta: Salemba Empat

Finney, Martha. 2011. ENGAGEMENT: Cara Pintar Membuat Karyawan Mencurahkan Kemampuan Terbaik untuk Perusahaan. Jakarta: PPM

Fitrianna, Nurma dan Tri Siwi Agustina. 2015. "Transformational Leadership dan Commitment to Change: Dimediasi oleh Readiness for Change Studi pada Karyawan PT. Telkom Divisi Regional V Surabaya" Jurnal Manajemen Bisnis Indonesia (Februari), hal 154-167.

Ghozali, Imam. 2011. Aplikasi Analisis Multivariate Dengan Program IBM SPSS 19. Semarang : Badan Penerbit UNDIP

Holt, Daniel T, Achilles A. Armenakis, Hubert S. Field, dan Stanley G. Harris. 2007. "Readiness for Organizational Change: The Systematic Development of a Scale" Journal of Applied Behavioral Science (Juni), hal. 232-255.

Kartika, Latifa Dewi. 2016. Pengaruh Transformational Leadership 
terhadap Readiness for Change melalui Employee Engagement sebagai variabelintervening pada karyawan PT. SUPARMA, Tbk. Tesis. Surabaya: Universitas Airlangga.

Kreitner, Robert, dan Angelo Kinicki. 2014. Perilaku Organisasi. Jakarta: Salemba Empat.

Kreitner, Robert, dan Angelo Kinicki. 2015. Perilaku Organisasi. Jakarta: Salemba Empat.

Laensadi, Azkya Milfa. 2015. Pengaruh Persepsi Kepemimpinan Transformasional dan Faktor Demografik terhadap Kesiapan dalam Menghadapi Perubahan Mekanisme Kerja Organisasi. Skripsi. Jakarta: Universitas Islam Negeri Syarif Hidayatullah.

Lensufiie, Tikno. 2010. Leadership untuk Profesional dan Mahasiswa. Jakarta: Esensi Erlangga Group

Luthans, Fred. 2006. Perilaku Organisasi. Yogyakarta: Penerbit ANDI.76

Megani, Astelita. 2012. Hubungan antara Employee Engagement dan Kesiapan karyawan untuk berubah (studi PT. X). Skripsi. Depok: Universitas Indonesia.

Muhtada, Irsyad. 2009. Hubungan antara Perilaku Prososial Profesi Perawat dengan Komitmen Organisasi di Rumah Sakit. Skripsi. Yogyakarta: Universitas Ahmad Dahlan.

Mujiasih, Endah. 2015. "Hubungan antara Persepsi Dukungan Organisasi (Perceived Organizational Support) dengan Keterikatan Karyawan (Empoyee Engagement)" Jurnal Psikologi Undip (April), hal. 40-51.
Nawawi, Ismail. 2014. Manajemen Perubahan: Teori dan Aplikasi pada Organisasi Publik dan Bisnis. Bogor: Ghalia Indonesia.

Nugraheni, Astuti Lia. 2012. Pelatihan Self Efficacy untuk Meningkatkan Kesiapan dalam Menghadapi Perubahan pada Karyawan PT PLN (Persero) Pusdiklat. Tesis. Depok: Universitas Indonesia.

Nurafiah, Fifi. 2012. Pengaruh Gaya Kepemimpinan Transformasional terhadap Komitmen Organisasi pada PT. Bank XYZ, Tbk Cabang Tanggerang. Skripsi. Depok: Universitas Indonesia

Periantalo, Jelpa dan Wilman D. Mansoer. 2008. "Faktor - Faktor yang Mempengaruhi Kesiapan untuk Berubah Pegawai di DIRJEN PQR" Jurnal Pasca Sarjana (September), hal. 195-203.

Rachmawati, Meida. 2010. "Employee Engagement sebagai Kunci Meningkatkan Kinerja Karyawan (International Journal Review)" International Journal of Business and Management (Desember), hal. 5265.

Rimata, Ega Praja. 2014. Pengaruh Komitmen Organisasi dan Motivasi Kerja terhadap Kepuasan Kerja Karyawan PT. Pos Indonesia Yogyakarta. Skripsi. Yogyakarta: Universitas Negeri Yogyakarta.

Robbins, Stephen P. dan Mary Coulter. 2008. Pengantar Manajemen. Jakarta: Erlangga.

Robbins, Stephen P., dan Timothy A. Judge. 2017. Perilaku Organisasi. Jakarta: Salemba Empat. 
Saks, Alan M. 2006. "Anteceden and consequences of employee engagement" Journal of Managerial Psychology (Juni), hal. 600-619.

Santosa, T. Elisabeth Cintya. 2012. "Memahami dan Mendorong Terciptanya Employee Engagement dalam Organisasi” Jurnal Manajemen (Mei), hal. 2007-2015.

Setiawan, Bahar Agus, dan Abd. Muhith. 2013. Transformational Leadership: Ilustrasi di Bidang Organisasi Pendidikan. Jakarta: PT. RajaGrafindo Persada.

Sugiyono. 2015. Metode Penelitian Kuantitatif, Kualitatif, dan R\&D. Bandung: Alfabeta

Vidal, Matt. 2007. "Lean Production, Worker Empowerment, and Job Satisfaction: A Qualitative Analysisand Critique" Critical Sociology, hal. 247-278.

Wibowo. 2012. Manajemen Perubahan. Jakarta: PT. RajaGrafindo Persada.

Zulganef. 2008. Metode Penelitian Sosial dn Bisnis. Yogyakarta: Graha Ilmu

Zulkarnain, dan Sherry Hadiyani. 2014. "Peran Komitmen Organisasi dan Employee Engagement terhadap Kesiapan untuk Berubah" Jurnal Psikologi (Juni), hal. 19-35 